\title{
COPYRIGHT ASSIGNMENTS AND THE CAPITAL GAINS TAX
}

\author{
CARL H. FULDAT
}

Publication of General Eisenhower's wartime memoirs was eagerly awaited by all Americans, but only a few realized that the author was forced to come to grips with one of the most vexatious problems of tax law. Apparently, the General accepted an offer from a newspaper syndicate to sell the book, film and magazine rights to his memoirs "in one whole package." Inquisitive reporters soon discovered that as long as a non-professional writer" "disposed of all his rights in the memoirs 'as one whole package,' and retained no further ownership whatever thereto, the transaction could come under the heading of a capital gain, on which a lower tax rate would apply." 2

Despite General Eisenhower's substantial tax saving-an all too modest reward for his accomplishments-it seems strange that the sale of all rights in a copyrightable work should be a prerequisite for subjecting the author's gain to the capital gains tax. Why should the much higher tax rate for ordinary income be imposed if the author separately transfers such apparently substantial parts of the copyright as book, movie, or dramatization rights?

\section{I}

The distinction between assignment of all and of part of the rights included in the "bundle" of section one of the Copyright Act" focuses attention upon the central problem of capital gains tax law-the ascertainment of whether there has been a "sale" of a capital asset." If

$\dagger$ Assistant Professor of Law, Rutgers University.

1. N. Y. Times, June 2, 1948, p. 31, col. 1 .

2. N. Y. Times, Jan. 2, 1948, p. 29, col. 5. The copyright must be held by the owner for at least six months in order for its sale to be treated under capital gains tax provisions. INT. REv. ConE $\$ 117$ (b).

3. The Copyright Act provides that a person entitled to a copyright, upon compliance with the provisions for registration and deposit of copies (17 U.S.C.A. $\$ \$ 5,10,11,13$ (Supp. 1947)) shall have several "exclusive rights" which are specifically enumerated in the five subdivisions of section 1 of the statute, 17 U.S.C.A. $\$ 1$ (Supp. 1947). They include, for instance, the right to print, publish and sell copies (subdivision $a$ ), the right to translate, to dramatize, to convert into a novel (subdivision $b$ ), to perform publicly, to make transcriptions or records, to exhibit (subdivision $d$ ), and to reproduce mechanically (subdivision $\varepsilon$ ). See 1 Ladas, The Internatronal Protectjozt of Literany asto Arutstic PROPERTY 2 (1938) who points out that "the term [copyright] is inapt today when applied to the aggregate of prerogatives accorded authors. ..." (Citations used in this article are from U.S.C.A. (Supp. 1948), and follow the section numbers of the 1947 act, which renumbered and reenacted the 1909 copyright statute).

4. It is elementary that the lower tax rate on long-term capital gains applies only where a capital asset has been sold. "Capital asset" is statutorily defined as all "property" 
there has been something less than a sale, the capital gains tax is inapplicable. Although the abstract criteria for solution of the problem are easily found-i.e. that there be "a final disposition" in the nature of an "out-and-out transfer of a substantial and durable property interest" with no power of control retained by the transferor"-they provide little more than an outline without content. Once translated into copyright terms, however, the outline loses some of its vagueness. With literary property, as with other forms of property, the most reliable index of ownership is the right of exclusion ${ }^{6}-$ or, in copyright law, the right to "restrain the spontaneity of men" by means of an infringement suit. "Where such a right to exclude others from enjoyment has been transferred, the transferee may well be considered the owner for tax purposes-especially since tax law is primarily concerned with beneficial ownership rather than with "refinements of title." 8

In the copyright cases, the answer to the problem of when there has been a sale with its attendant right to sue for infringement has been

held by the taxpayer, subject to certain specifically enumerated exceptions. INT. REv. CoDE $\$ 117$ (a) (1). See generally, 3 Mertens, Law of Federal Inconse Taxation $\$ \$ 22.04$, $22.12(1942)$.

5. See the definition in Uniform Sales Act $\S 1$. See, 1 Wiluiston, Sales, c. XIV (2d ed. 1924). Williston points out in $\$ 9$ a that "a mortgage at common law transfers title to the mortgagee, but only for the purpose of securing payment of a debt. A security title in the various forms which it takes ... requires careful discrimination from absolute sales." A sale is also to be distinguished from a contract giving an exclussive license. For tax cases on this problem, see Irving Berlin v. Commissioner of Internal Revenue, 42 B.T.A. 668, 674 (1940) ;McAllister v. Commissioner of Internal Revenue 157 F.2d 235, 237 (2d Cir. 1946), cert. denied, 330 U.S. 826 (1947). Compare the analogous problem of Commissioner of Internal Revenue v. Sunnen, 333 U.S. 591, 604, (1948) : Assignment by taxpayer to his wife of all his rights, title and interest in various patent licensing contracts with corporation controlled by him held ineffective to shift liability for income tax on royalties to assignee as taxpayer retained control over such royalties."

6. That copyright statutes deal with the copyright as property, sec American Tobacco Co. v. Werckmeister, 207 U.S. 284, 291 (1907); Universal Pictures Co. v. Harold Lloyd Corporation, 162 F.2d 354, 369 (9th Cir. 1947). Cf. White-Smith Music Pub. Co. v. Apollo Co., 209 U.S. 1, 19 (1908).

7. American Tobacco Co. v. Werckmeister, supra note 6 (a writing delivered by a painter to plaintiff, purporting to transfer the copyright in a designated picture, held to amount to "complete transfer of the property right of copyright existing in the picture" and thus entitling plaintiff to maintain infringement suit). See 17 U.S.C. $\$ 101$ (Supp. 1947). The famous passage quoted in the text is found in Mr. Justice Holmes' concurring opinion in White-Smith Music Pub. Co. v. Apollo Co., 209 U.S. 1, 19 (1908). It was his contention that in copyright the notion of property has reached "a more abstract cxpression" in that "the right to exclude is not directed to an object in possession or owned, but is in vacuo, so to speak. It restrains the spontaneity of men where, but for it, there would be nothing of any kind to hinder their doing as they saw fit."

8. Corliss v. Bowers, 281 U.S. 376, 378 (1930), quoted with approval in Griffiths v. Helvering, 308 U.S. 355,357 (1939). As to the definition of the term "property," see 3 Mertens, Federai Income Taxation $\$ 20.30$. 
supplied by the doctrine of the indivisibility of a copyright-the conceptual parent of tax law's "one package" rule. The doctrine has been used to rationalize the conviction that a transfer of less than all of the rights conferred by section one of the Copyright Act ${ }^{\circ}$ makes the transferee a "mere licensee," 10 entitled to less judicial aid than an "assignee"-proprietor. ${ }^{11}$

The clearest exposition of this view may be found in Witmark \& Sons v. Pastime Amusement Co. ${ }^{12}$ Plaintiff, owner of the copyright in a song by Victor Herbert, had executed an "assignment" to the American Society of Composers, Authors, and Publishers, purporting to transfer for a specified time the exclusive right of public performance for profit. When the defendant played the song in his motion picture theatre, plaintiff sued for infringement. The court held that plaintiff, and not the Society, was the "proprietor" of the copyright and, therefore, the proper party to assert the clain for infringement. In reaching this decision, it was pointed out that plaintiff had not parted with his entire interest in the copyright, but that the copyright had been only partially assigned. The court then concluded:

"In relation to the right to sue for an infringement, a copyright is an indivisible thing, and cannot be split up and partially assigned either as to time, place, or particular rights or privileges, less than the sum of all the rights comprehended in the copyright. Certainly the statute authorizing assignments of copyright contains no recognition of such partial assignments. Of course, such exclusive rights may be granted, limited as to time, place, or extent of privileges which the grantee may enjoy; but the better view is that such limited grants operate merely as licenses, and not as technical assignments, although often spoken of as assignments." 13

The court's obvious implication-that the Society, being a mere licensee and not a "proprietor," would not have been able to maintain a suit for infringement-was supported by earlier authorities. For example, in New Fiction Publishing Co. v. Star Co., ${ }^{14}$ the author and copyright owner of a play assigned to the plaintiff the "serial rights," which included all rights to publish, except the right to publish the play as a book and the right of dramatic performance. Plaintiff printed

9. See note 3 supra.

10. See 13 C.J. 1048. The licensee's rights are said to be of a contractual nature New Fiction Pub. Co. v. Star Co., 220 Fed. 994, 996 (S.D.N.Y. 1915).

11. See generally, Axspur, Copyright Law and PRACtice 7\&S-S03, 913-924 (1936); 13 C.J. 1094-1096; 1S C.J.S. \$83; Bali, The Law of Copyrugut amd Limrrary Property 46 (1944).

12. 298 Fed. 470 (E.D.S.C. 1924), aff'd per cturian 2 F.2d 1020 (4th Cir. 1924).

13. Id. at 474, 475; accord; Eliot et al. v. Geare-1larston, Inc, 30 F. Supp. 301 (E. D. Pa., 1939).

14. 220 Fed. 994 (S.D.N.Y., 1915). 
the play in his magazine, but shortly before the issue containing the play was put in circulation, defendant printed substantial portions of the play in his newspaper. In dismissing plaintiff's suit for infringement, the court observed that "less than an assignment of the entire copyright cannot carry the causes of action . . . which the act accords to the owner or assignee." 15 This interpretation of the statute as recognizing only one general, all-embracing copyright, but no separate rights, ${ }^{16}$ was apparently based on the language of the provisions governing assignments and infringement suits. Assignments must be executed by the "proprietor"; ${ }^{17}$ similarly only a "proprietor" may sue for infringement. ${ }^{18}$ The court reasoned that since the author had sold only a limited right to plaintiff and another limited right to a theatrical manager, he obviously did not intend completely to divest himself of his copyright by assignment. And the specter of multiple suits against the alleged infringer was raised to justify the requirement that the "owner" appear as plaintiff, the court saying: "They [the remedies here sought] were not intended to be cumulative, so as to subject a defendant to more than one recovery for the redress of one wrong." 10 Significantly, the court added in a footnote that a different situation might be presented if the author-owner himself were the plaintiff. ${ }^{20}$

The theory of the indivisibility of the copyright ${ }^{21}$ which made the owner a necessary party to any suit for infringement followed a similar doctrine in the field of patent law. ${ }^{22}$ Like the copyright proprietor, the

15. Id. at 996 .

16. Ibid., quoting from Bowker, COPYRIGHT, Its History AND ITS LAw 49 (1912); "There can be no such thing as a copyright for a special purpose, or for a special locality, or under other special conditions, for there can be only one copyright, and that a general copyright, in any one work."

17. 17 U.S.C.A. $\$ 28$. The assignee of a duly recorded assignment may substitute hils name for that of the original owner-assignor in the required statutory notice, 17 U.S.C.A. $\$ 32$; as to the original copyright notice which must be affixed to each copy of a copyrighted work see 17 U.S.C.A. $\$ \S 10,19,20,21$.

18. 17 U.S.C.A. $\$ 101$ (b).

19. 220 Fed., at 996.

20. Id. at $997 \mathrm{n}$.

21. See, in addition to the cases discussed, Jefferys v. Boosey, 4 H.L. 815, 993, 10 Eng. Rep. 681, 751 (1854) ; Keene v. Wheatley, 14 Fed. Cas. 180, 186 No. 7,644 (E.D. Pa. 1861); compare Public Ledger v. New York Times, 275 Fed. 562,564 (S.D.N.Y. 1921) (". . . the author's rights may not be divided except as the statuto recognizes it division, and ..., if he retains a part of what goes to make up any of the recognized divisions, his assignee is not a proprietor."), aff'd on other grounds, 279 Fed. 747 (2d Cir. 1922), cert. denied 258 U.S. 627 (1922); Kaplan v. Fox Film Corporation, 19 F. Supp. 780 (S.D.N.Y. 1937) ; Fitch v. Young, 230 Fed. 743, 745 (S.D.N.Y. 1911), aff'd., 239 Fed. 1021 (2d Cir. 1917); Bobbs-Merrill Co. v. Straus, 147 Fed. 15, 24 (2d Cir. 1906) ("The copyright statute provides only for the assignment of the right as a whole.").

22. See Wolff, Copyright Lazu and Patent Law, a Comparison, 27 Iows L. Rev. 250 (1942), for a collection of authorities treating copyright and patent problems as similar. 
owner of a patent has "the exclusive right to make, use, and vend the invention or discovery." ${ }^{23}$ Apparently, the copyright cases merely adopted the previously established philosophy of the patent cases which held that a transfer of less than all three of the rights comprising the patent monopoly is not a transfer of title in the patent but only a license, which gives the licensee no right to sue for infringement. ${ }^{24}$

\section{II}

A superficial examination of the theory of indivisibility might create the impression that the lot of the "licensee" is not a happy one; he does not have the magic attribute of "title" and therefore seems to be deprived of the essential power to restrain "the spontaneity of men." However, such an impression would be utterly misleading. The "licensee" need not worry about his lack of "title"; courts lnow how to

For the specific problem of indivisibility, see id. at 265-6; Empire City Amusement Co. v. Wilton, 134 Fed. 132, 133 (D. Mass., 1903) ("The licensee under a patent cannot sue alone in his own name, and every partial assignee of patent rights, who does not talie an undivided part of the whole patent or a territorial share of the whole patent [or, perhaps, an undivided part of a territorial share], is deemed a mere licensee. REv. Srar. $\S 4898$ [35 U.S.C.A. \$ 47] . . , Gaylor v. Wilder, 10 How. 477, 494, (U.S. 1850). Section 4954 [17 U.S.C.A. $\$ 28$ ] . . . , which deals with the assignment of copyright, is similar ..., and by analogy it seems that an assignee of "the exclusise right to dramatize" is a mere licensee, and so cannot sue in his own name"). For comparisons with the law of trademarks, see infra p. 264.

23. 35 U.S.C.A. $\$ 40$. One marked difference between copyright and patent statutes is that the latter includes a clause authorizing assignments of patents for a limited territory.

24. In Gayler v. Wilder, 10 How. 477, 494, 495 (U.S. 1850) Chief Justice Taney declared that "the monopoly granted to the patentee is for one entire thing; it is the exclusive right of making, using and vending...." In order to enable the assignce to sue, "the assignment must undoubtedly convey to him the entire and unqualified monopoly which the patentee held in the territory specifed-excluding the patenter himself, as well as others. And any assignment short of this is a mere license For it was obviously not the intention of the Legislature to permit several monopolies to be made out of one, and divided among different persons within the same limits. Such a division would inevitably lead to fraudulent impositions upon persons who desired to purchase the use of the improvement, and would subject a party who, under a mistalie as to his rights, used the invention without authority, to be harassed by a multiplicity of suits instead of one, and to successive recoveries of damages by different persons holding different portions of the patented right in the same place. Unquestionably, a contract for the purchase of any portion of the patent right may be good as between the parties as a license, and enforced as such in the courts of justice. But the legal right in the monopoly remains in the patentee, and he alone can maintain an action against a third party who commits an infringement upon it." Accord: Waterman v. Mackenzie, 138 U.S. 252 (1891); United States v. General Electric, 272 U.S. 476, 489 (1926). The cases are collected in 35 U.S.C.A. \$67, n. 117. See, generally, 48 C.J. 239-243. And see Goldwyn Pictures Corp. v. Howells Sales Co., 282 Fed. 9(2d Cir. 1922); Fitch v. Young, 230 Fed. 743 (S.D.N.Y. 1911), aff'd 239 Fed. 1021 (2d Cir. 1917) ; Loeal Trademarlis v. Powers, 56 F. Supp. 751 (E.D. Pa. 1944). 
handle words ${ }^{25}$ and it is therefore easy to demonstrate that, although he lacks legal title, he enjoys an equitable title which protects him quite adequately.

Here again, the copyright law has merely followed the path marked out by the patent law. In the early case of Littlefield $v$. Perry, ${ }^{20}$ the Supreme Court considered the situation of a licensee whose rights had been violated by his licensor, the patent owner; the obvious absurdity of the argument that the licensee's inability to sue should bar relief against his licensor was met by the statement that in this case, the person who should have protected the licensee against all infringements had himself become the infringer. $\mathrm{He}$, the infringer, "held the legal title to his patent in trust for his licensees. He has been faithless to his trust, and courts of equity are always open for the redress of such a wrong. This wrong is an infringement." Half a century later, in Independent Wireless Telegraph Co. v. Radio Corporation of America, ${ }^{27}$ the Court applied the general principle that "a cestui que trust may make an unwilling trustee a defendant in a suit to protect the subject of the trust," and concluded that:

". . . the implied obligation of the licensor to allow the use of his name [as coplaintiff] is indispensable to the enjoyment by the licensee of the monopoly which by personal contract the licensor has given.... If there is no other way of securing justice to the exclusive licensee, the latter may make the owner . . . a coplaintiff without his consent in the bill against the infringer." 23

The patent law rule has been adopted by the courts as the guiding principle controlling copyright assignments. As early as 1890 , it was said that the theory of the indivisibility of a copyright implied "no restriction upon the power of the proprietor to assign or transfer, in equity, an exclusive right to use the copyrighted book in a particular manner or for particular purposes upon such terms and conditions as

25. See Laube, A Glossatorial Study, 28 Georgetown L.J. 763 (1940); State v. Hedrick, 272 Mo. 502, 199 S.W. 192 (1917), where it is pointed out that "the carcass of a hog, by whatever name called, is not a hog."

26. 21 Wall. 205,223 (U.S. 1875).

27. 269 U.S. 459,469 (1926).

28. Id. at 469,472 . The decision was cited by the Advisory Committee on Rulcs of Civil Procedure as an example of a proper case for the necessary joinder of an involuntary plaintiff pursuant to Rule 19 (a) of the Federal Rules of Civil Procedure. See 2 Moone's Federal Practice $\$ 19.02$, pp. 2134, 2143 (1948). The Federal Rules of Civil Procedure are applicable to actions for the infringement of copyrights: FED. R. Civ. P., 81(a) (1); 17 U.S.C.A. $\$ 101$ (f); Rules adopted by the Supreme Court of the United States for Practice and Procedure under the Copyright Act, Rule 1, as amended June 5, 1939. Cf. Stephens v. Howells Sales Co., 16 F.2d 805 (S.D.N.X. 1926). 
may be agreed upon." ${ }^{29}$ In Page \& Co. v. Fox Film Corporation, ${ }^{20}$ the court went even further in disregarding "refinements of title" when it voiced the opinion that "it is immaterial whether the plaintiff's rights be considered to be merely contractual or to involve the grant of a proprietary interest in the copyright. . . " As an exclusive licensee, the plaintiff could invoke the rule of the Independent Wrireless Telegraph Co. case; he ". . . could compel the copyright proprietor, as a trustee, to sue for an infringement, even if no "interest" was transferred to the plaintiff." 31

Parenthetically, it might be indicated that the rule of compulsory joinder of the owner-licensor provides the back-bone of the practice of the American Society of Composers, Authors, and Publishers. ${ }^{32}$ That organization usually receives from its members the exclusive right to perform their musical compositions publicly for profit and undertakes to protect itself and its members from piracy and plagiarism. Following the Witmark case, ${ }^{33}$ it has been consistently held that ASCAP, as a licensee, could bring suit for infringement only by compelling the owner of the copyright to be joined as a necessary party plaintiff, the rationale being that only in this way could a defendant be protected from harassment by successive law suits. ${ }^{34}$

29. Black v. Henry G. Allen Co., 42 Fed. 618, 621 (C.C.S.D.N.Y. 1890). In that case the "proprietor" and the "assignee" had voluntarily joined as plaintiffs.

30. 83 F.2d 196, 198 (2d Cir. 1936). See generally, Ball, op. cit. sispra note 11, §310, at pages 691-693.

31. Page \& Co. v. Fox Film Corp., supra note 30, at 198 (italies supplied).

32. For a description of the practices of that organization, see, Judicial Dccisions Irvolving ASCAP, 136 A.L.R. 1438 (1942).

33. See note 12 supra.

34. Buck v. Elm Lodge, 83 F.2d 201 (2d Cir. 1936), citing Independent Wireless Telegraph Co. v. Radio Corp., 269 U.S. 459 (1926); and Buck v. Jewell-La Salle Realty Co., 283 U.S. 191 (1931) (infringement suit brought jointly by ASCAP and an individual member; no discussion of the problem); Buck v. Royal Palms, Inc, 23 F. Supp. 29 (D.MTass. 1938); Buck v. Virgo, 22 F. Supp. 156 (W.D.N.Y. 1938); Buck v. Russo, 25 F. Supp. 317, 321 (D. Mass. 193S) (stresses necessity of joining copyright owner, as damages will go to Scciety and defendant "will be subjected to only one trial where he may defeat all claims or by satisfying one adverse decree bar all subsequent actions.") ; Society of European Stage Authors and Composers, Inc. v. WCAU Broadcasting Co., 25 F. Supp. 3S5 (E.D. Pa, 1938) (refers to licensee as "beneficial owner" and grants licensee's motion to bring in copyright owners as new parties plaintif on the ground of "joint interest" within Rule 19 (a), Federal Rules of Civil Procedure). The copyright "owner," as holder of "legal title," may sue an infringer in his own name without being required to join ASCAP as co-plaintiff. Widensli y. Shapiro, Bernstein \& Co., 147 F.2d 909 (1st Cir. 1945) (pointing out that, in view of ASCAP's inability to sue alone, the defendant, in a suit brought by the copyright owner, is fully protected from a second suit for the same infringement) ; E. B. Miarks Miusic Corp. v. Terry Vogel Music Co., 140 F.2d 268 (2d Cir. 1944) ; Leo Feist, Inc. v. Young, 138 F.2d 972 (7th Cir. 1943) (ASCAP is merely an agent of the owner). 


\section{III}

The "licensee," meaning the person to whom less than the sum total of all the rights included in the copyright has been transferred, now emerges as the owner of an "equitable title" or as "assignee of an equitable interest." His power to defend his position against all comers is subject only to the formality of joining the "proprietor" as a nominal party plaintiff. Thus, only the procedural technicality of compulsory joinder prevents the licensee from having that earmark of ownershipthe unbridled right to sue for infringement-which would vest him with "actual command of the property." 35

Not only has the indivisibility theory been sidestepped by procedural agility, but its substantive soundness has repeatedly been questioned and even repudiated. As early as 1860 , a federal court in Massachusetts granted an injunction to prevent performance of a drama despite defendant's objection that plaintiff was merely a licensee who possessed the exclusive right of public performance for only a limited period and a limited territory. ${ }^{36}$ The Copyright Act in force at the time did not differ in any material respect from the present statute. ${ }^{37}$ The Court observed that the act sanctioned assignments, but did not specify what interest might be assigned; hence, there was:
“ . . . no sufficient reason for preventing the author from con- veying a distinct portion of his right. Divisibility as well as assig- nability enhances the value of his property, for he may find a pur- chaser able and willing to pay for a part, but not for the whole of his copyright. The exclusive right of acting and representing is distinct from that of prinitng and publishing, . . . and there is no good reason why it should not be assignable, and that too, for a limited time. The Respondent is a mere wrongdoer who has invaded this copyright, and intends further to invade it within the time and ter- ritory which the author, for a valuable consideration, has trans- ferred to the complainant." 38

In addition, the Court rejected the contention that the suit should have been brought by the author, or at least by the plaintiff jointly with the author; since the author's interest had not been invaded and the defendant was in no danger of being sued by the author, the re-

35. This has been clearly recognized only by the majority opinion in Wodehouso v. Commissioner of Internal Revenue, 166 F.2d 986, 989 (4th Cir. 1948), cert. grantcd, 17 L.W. 3090 (Oct. 11, 1948).

36. Roberts v. Myers, 20 Fed. Cas. 898 , No. 11,906 (C.C.D. Mass. 1860 ).

37. The Act of February 3, 1831 (4 STAT. 436-9, 21st Cong., 2d Sess., c. 16) referred to the "legal proprietors" of the copyright as being entitled to the remedies provided by the Act ( $(15)$; The Act of June 30, 1834 (4 Stat. 728, 23rd Cong., 1st Sess., c. 157) provided for the recording of "all deeds or instruments in writing for the transfer or assignment of copyrights."

38. Roberts v. Myers, 20 Fed. Cas. 898, 900, No. 11,906 (italics supplied). 
quirement of joining the author as a coplaintiff "would be an idle and nugatory act, beneficial to no-one." 39

Business realities as well as emergent legal doctrines cast doubt upon the indivisibility theory. Even a cursory glance at commercial practice reveals that the various rights enumerated in section one of the Copyright Act-e.g. right to print, dramatize, record-"are inherently and essentially different. They are, in most cases, exercised or purchased by different persons" 40 and extend to such widely divergent industries as the book publishing trade, the newspaper or magazine publishing industry, the legitimate stage and the motion picture producer. ${ }^{41}$ The value of each one of these distinct rights may be separately computed ${ }^{42}$ and "the copyright owner has the right to sell such portion of his copyright as he desires." 43 It should also be noted that many of the separate rights of the copyright owner may be used as a basis for securing new and separate copyrights. For instance, the copy-

39. Ibid. Accord, Aronson v. Fleckenstein, $2 S$ Fed. 75, 7S (N.D.Ill. 1E\&6) (exclusive licensee of performing rights for two years, who, by the terms of the license, is to bring all necessary suits for the protection of his rights, held entitled to injunction). 1906).

40. Ford v. Charles E. Blaney Amusement Co., 148 Fed. 642, 645 (C.C.S.D.N.Y.

41. The catalogue of exclusive rights in $\$ 1$ of the Act (61 SrAT. 652 (1947), 17 U.S.C.A. \$1) does not mention the term "motion picture"; however, the term is used in the provisions establishing a classification of works for registration (61 STAr. 652 (1947), 17 U.S.C.A. \$ 5 (1), and relating to works not reproduced for sale (61 STAT. 652 (1947), 17 U.S.C.A. $\$ 12$ ). As far as the coverage of $\$ 1$ is concerned, motion pictures are "dramatic works" within the meaning of paragraph $d$ of that section. Universal Pictures Co. v. Harold Lloyd Corp., 162 F.2d 354, 359 (9th Cir. 1947).

42. Interstate Hotel Corp. v. Remick Miusic Corp., 157 F.2d 744 (Sth Cir. 1946). The court gave judgment for plaintiff in infringement suit based on unauthorized public performance of plaintiff's music. Rejecting the argument that publication and sale as sheet music amounted to a waiver on the part of plaintiff, the Court said that the right to publish and sell copies ( $\$ 1$ (a)) and the right to perform publicly for profit (\$1 (e)) are "separate and distinct rights separately granted by the Copyright Act" and that "nothing in the Act... makes the exercise of one right dependent upon the abandonment of the other."

43. Murphy v. Warner Bros., 112 F.2d 746, 74S (9th Cir. 1940). Summary judsment for defendant was affirmed in action for infringement of plaintiff's play. Pursuant to the contract between the parties, plaintiff "agrees to, and by these presents does grant, bargain, sell, assign, transfer and set over . . . to the purchaser . . . the csclusive, complete and entire motion picture rights ... throughout the world, together with all the benefits of the copyright in such writings, the title and the theme thereof, and of all remedies held thereunder, with respect to such motion picture rights." The court rejected plaintiff's contention that the contract must be interpreted according to custom which excludes talking motion picture rights, as inconsistent with the language of the contract. See Buck v. Swanson, 33 F. Supp. 377, 387 (D.Neb. 1939), recersed on other grounds subnornizze MFarsh v. Buck, 313 U.S. 406 (1941). "The right of an author in his intellectual production is . . . assignable and it may be sold and transferred in its entirety; or a limited interest therein, less than the whole property, may be sold and assigned, and the various rights included in the entire oumership may be split us and assigned to different persons." (Italics supplied). 
right owner of a novel has the right "to dramatize it"; 44 he may secure a copyright for the dramatic version, and he may also write a motion picture scenario based on the novel and copyright that separately. ${ }^{45}$ It would seem that, since the copyright owner can do all these things, he also "could sell separately the right to dramatize and the right to make a moving picture play." 46

Even the merely procedural justification of the indivisibility doctrine is not entirely convincing. It rests on the ground that a defendant must be protected from being sued twice for the same wrong by requiring infringement suits to be brought by the "proprietor," either alone or jointly with the "licensee," but never by the "licensee" alone. This rule presupposes that if the "licensee" were to sue alone, the "proprietor" could sue again on the same cause of action. Such an assumption overlooks the fact that, at the very least, the legal owner would be estopped from asserting any such separate claim by reason of his contract with the licensee; the latter is deemed to be the beneficial owner who has had the same claim determined in the proceeding brought by him. ${ }^{47}$

Only the application of familiar principles of the law of trusts, which generally permits only the trustee (legal owner) and not the beneficiary (cestui) to sue third persons, ${ }^{48}$ would support the prevailing view that

44. 61 SтAт. 652 (1947), 17 U.S.C.A. \$ 1 (b) (Supp. 1948).

45. Photo Drama Motion Picture Co. v. Social Uplift Film Corp., 213 Fed. 374, 377 (S.D.N.Y. 1914), aff'd. 220 Fed. 448, 449 (2d Cir. 1915); see, 61 Stat. 652 (1947), 17 U.S.C.A. $\$ 5 \pi$ Tा(d) and (1), providing for separate copyrights for dramatic compositions and motion picture photoplays. It was first held in Kalem Co. v. Harper Bros., 222 U.S. 55 (1911) that the right to dramatize included the right to make motion picturo scenarios.

46. Learned Hand, $J$, in Photo Drama Motion Picture Co. v. Social Uplift Film Corp. 213 Fed. 374, 377 (S.D.N.Y. 1914). To same effect see, Carte v. Ford, 15 Fed. 439, 442 (C.C.Md. 1883) (referring to the "two distinct and separable rights" of printing and public performance); Ford v. Charles E. Blaney Amusement Co., 148 Fed. 642 (S.D.N.Y. 1906). Cf. Goldwyn Pictures Corp. v. Howells Sales Co., 282 Fed. 9 (2d Cir. 1922) (court distinguishes the Photo Drama Motion Picture case on the ground that in the latter case the transferee of the motion picture rights had actually secured a new and independent copyright on the completed motion picture). Sec New Fiction Publishing Co. v. Star Co., 220 Fed. 994 (S.D.N.Y. 1915) (court indicated that the separate "estates" which make up the copyright "may be sold and assigned scparately" by "specific contracts ... enforceable under the law of contracts" (quoting from BowkER oN COPYRIGET 49 (ed. 1912)), thus contradicting its own theory of indivisibility).

47. In Commissioner of Internal Revenue v. Sunnen, 333 U.S. 591, 597 (1948) the Supreme Court said that "the general rule of res judicata applies to repetitious suits involving the same cause of action." Perhaps the legal owner would also be liable to the defendant in tort for malicious prosecution. See Prosser on Torts, 885 (1941). On the other hand, it should be noted that, under familiar principles of the law of trusts, actions against third persons may be maintained only by the trustee as holder of the legal title. 2 Scotr, The LAw of Trusts $\$ \$ 281,282$ (1939).

48. See Scott, op. cit. supra note 47; Restatement, Trusts \$\$281, 282. 
the legal owner is a necessary party plaintiff. Yet even this begs the question because it postulates, without explanation, that the copyright cannot be split up into its component parts. Significantly, some courts have altogether ignored the rule that the legal owner must always be a plaintiff in the action. Thus, where the copyright is taken out by the publisher pursuant to an agreement that the publisher shall hold it only as trustee for the benefit of the author, the latter has "full equitable title" and may bring suit in his own name, not only against an unfaithful trustee, but also against third persons. ${ }^{49}$ So also, while damages under the statutory action for infringement must be paid "to the copyright proprietor," 50 injunctions may be granted "upon complaint filed by any party aggrieved." 51 At least one court, with seemingly unassailable logic, has held that this phrase must be construed as including a "licensee" of the right of mechanical reproduction of copyrighted music, ${ }^{52}$ as the statutory language "is not limited merely to owners of the copyright, but is broad enough to include licensees. . . ." 53 In addition, the licensee might well be considered as the holder of a power coupled with an interest or given for security ${ }^{54}$ and as such entitled to sue in his own name. ${ }^{55}$

49. Bisel v. Ladner, 1 F.2d 436 (3rd Cir. 1924) (suit by author against his publisher and another infringer); Ted Browne Mrusic Co. v. Fowler, $290 \mathrm{Fed}$ 751, 753 (2d Cir. 1923) ("The owner of the equitable title is not a mere licensee, and he may sue in equity, particularly where the owner of the legal title is an infringer, or one of the infringers."); Witwer v. Harold Lloyd Corp., 46 F.2d 792, 795 (S.D. Cal. 1930), recersid on other grounds, 65 F.2d 1 (9th Cir. 1933), cert. destied, 78 L. Ed. 1507 (1933) (infringement suit by equitable owner against one other than the holder of the legal title); Henry Holt \& Co. v. Liggett \& Myers Tobacco Co., 23 F. Supp. 302, 304 (E.D. Pa. 1938) (another and equitable owner entitled to maintain suit in equity in his own name). Cf. Schellterg v. Empringham, 36 F.2d 991, 994 (S.D. N.Y. 1929) (holder of legal title joined author and equitable owner as party plaintiff, although the former "asks nothing, expects nothing and wants nothing for itself. It is present merely for the purpose of submitting itself to the court"'). See Southern Misic Pub. Co. v. Walt Disney Productions, 73 F. Supp. 580 (S.D.N.Y. 1947) ; T.B. Harms \& Francis, Day \& Hunter v. Stern, 229 Fed. 42 (2d Cir. 1915), 231 Fed. 645, 647 (2d Cir. 1916). Observe that under these cases we should have to distinguish between the author as owner of the "full" equitzble title and a licensee as owner of an equitable title which is certainly less than "full." The copyright notice, supra note 17 , is not even mentioned in these decisions.

50. 61 Stat. 652 (1947), 17 U.S.C.A. $\$ 101(b)$.

51. 61 Stat. 652 (1947), 17 U.S.C.A. $\$ 112$.

52. 61 STAT. 652 (1947), 17 U.S.C.A. \$1(e).

53. Aeolian Co. v. Royal Music Roll Co., 196 Fed. 926, 928 (W.D.N.Y. 1912).

54. Restatenient, Agency, 138 (1933); 1 Mifcheas, A Treatise obi the Law of AGENCY $\$ \$ 570-\$$ (2d Ed. 1914).

55. In Leo Feist, Inc. v. Young, 138 F.2d 972 (7th Cir. 1943), the court said that the "licensee" was the agent of the copyright owner and therefore only the latter was the real party in interest; it is submitted however, that the position of the "licensee" is ordinarily" much stronger than that of a mere agent whose sole aim is to serve the interests of the principal. 
This endless quibble about such labels as "legal title" and "equitable title" which runs through all of the copyright cases, appears to be somewhat frustrating. Those labels, as Judge Clark recently observed, are only "group symbols, denoting a bundle of rights or other legal relations" which are helpful in the solution of practical problems only "when we advance beyond these forms to the questions of degree, or of number and value of such rights." 56 Measured by such a yardstick, each one of the many exclusive rights which, together, make up the "bundle" of section one of the Copyright Act, would seem to be "substantial enough to be regarded as some form of property interest," and the assignment of any one of them as the sale of a capital asset. It is perhaps noteworthy that in the related field of trade-marks, agreements for the transfer of limited rights in a mark have been construed as assignments ${ }^{58}$ conveying "property rights in and to a business, good will, and trade-mark." 59

\section{IV}

When the Treasury first came to grips with the problem of copyright assignments, it held that an author's sale of the movie rights to his play fell within the categary of the sale of a capital asset." Subsequently, however, this ruling was reversed on the ground that a taxpayer who transferred either book, dramatic or motion picture rights

56. Standard Oil Co. v. Clark, 163 F.2d 917, 930 (2d Cir. 1947), cert. denied, 68 S. Ct. 902 (1948), noted 36 Georgetown L. J. 470 (1948).

57. Ibid. The court held that the right to recover patent royalties, to license, and to transfer rights in a patent "are some of the many elements of enjoyment making up title" and that "because of their substantial nature and their great monetary valuc," they are property interests for which a suit may be brought under $\$ 9(a)$ of the Trading with the Enemy Act to recover property allegedly wrongfully vested by the Alien Property Custodian. Compare the concurring opinion of Judge Frank, who disagreed with the liberal usage of the terms "property" and "title," 163 F.2d, at 937. Jutdge Clark's language, quoted in the text, is certainly applicable to copyrights; possibly, it could be argued that the various rights enumerated in $\$ 1$ of the Copyright Act are more diverse and distinct than the three rights to make, use and vend granted to a patentec.

58. 60 StaT. 431 (1946), 15 U.S.C. \$1060 (1946).

59. The Coca-Cola Bottling Co. v. The Coca-Cola Co., 269 Fed. 796, 816 (D. Del. 1920) (conveyance of right to use trade-mark in specific territory only in connection with bottled product, but not with fountain product); Andrew Jergens Co. v. Woodbury Inc., 273 Fed. 952, 960 (D.C.Del. 1921), aff'd per curiam, 279 Fed. 1016 (3rd Cir. 1922), cert. denied, 260 U.S. 728 (1922) (transfer of business and exclusive right to trademark except in so far as right to use the mark upon vendible commodities had previously been granted to others held to be an assignment, although agreement was designatcd as "license"). Accord; Fish Bros. Wagon Co. v. Fish Bros. Mfg. Co., 87 Fed. 203 (N.D. Iowa, 1898). Derenberg, Trade Mark Protection and Unfair Trading 571 et seq. (1936).

60. I.T. 2169, IV-1 Cum. Bulr. 13 (1925). This ruling was made under Section 208(a) (8) of the Revenue Act of 1924, which did not differ materially from Int. Rev. Code §117. See also O.D. 988, 5 Cum. BuLl. 117 (1921). 
had not conveyed the property "in its entirety," but had merely granted a license; therefore, the payments received were alin to rents or royalties which are taxable as ordinary income. ${ }^{.1}$ The Treasury thus adopted the "one package" rule, basing it upon the theory of the indivisibility of the copyright.

Any attempt to destroy the "one package" rule and thereby bring tax law into closer accord with both the facts of the market-place and the objectives of the capital gains provisions ${ }^{62}$ must be directed towards proving that any one of the "bundle of rights," known as copyright, is a "property right" and therefore, is as much a possible object of sale as stocks and bonds or real estate. ${ }^{63}$ The problem was squarely presented to the Second Circuit in 1944 when that court was called upon to determine whether payments made to an American playright for a

61. I.T. 2735, XII-2, Cuns. BurL, 131, 135 (1933). The decision applied the Revenue Acts of 1921, 1924, 1926 and 1928 to a non-resident alien author who had granted motion picture rights in his work to an American producer.

62. See, generally, Kent, The Question of Taxing Capital Gains: The Case for Taxation, 7 Laws \& Contenrp. Prob. 194 (1940), and Nelson, The Case Against Taxation, Id. at 208; Lowndes The Taxation of Capital Gains and Losses under the Federal Income Tar, 26 Tex. L.R. 440 (1948).

The objective of the capital gains tax was to remove the unfair burden of taxing, in the year when the profits are realized, a profit which has been earned and acerued during a relatively long holding period. Sec Fackler v. Commissioner of Internal Revenue 133 F.2d 509, 510, 511 (6th Cir. 1943), citing H. R. No. 350, Ways and Mreans Committee, 67th Cong. 1st Sess., page 10; Commissioner of Internal Revenue v. Holinson, 126 F.2d 406, 410 (2d Cir. 1942). The present holding period of more than six: months, 26 USCA, $\$ 117$ (a) (4) and (b) seems unreasonably short when considered in connection with the basic purpose of the lower tax rate. Lowndes, supro at 442. This encouragement to investment was, however, to be confined to irregular and fortuitous gains or losses. See Kent, supra at 200; Merchants' Loan \& Trust Co. v. Smietaniza, 255 U.S. 509 (1921). Otherwise, a windfall would result with respect to profits realized from regular and customary business activities. Consequently certain types of property such as stock in trade or property held by the taxpayer primarily for sale to customers "in the ordinary course of his trade or business" are expressly excluded from the benefit of the capital gains tax. Sale of their works by professional authors falls within this area of ineligibility. INT. REv. CODE, $\$ 117(a)(1)$; also excluded from the definition of "capital asset" is "property, used in the trade or business, of a character which is subject to the allowance for depreciation provided in IrrT. KEv. CoDE \$23(1)." The latter section originally applied only to "property used in the trade or business," but was amended in 1942 by making the depreciation allowance also applicable to "property held for the production of income" Patents and copyrights have always been considered as property subject to depreciation allowance where they have been used in the trade or business of the taxpayer. 4 MIERTENS, LAW OF FEDERAL INCOMIE TANATIOA $\$ 23.10$ (1942).

63. See Hale v. Helvering, 85 F.2d 819, \$21 (App. D.C. 1936). Note that in most of the copyright cases discussed above the transfer of rights to a licensee is referred to as a "sale." McDonald v. Commissioner of Internal Revenue, 76 F.2d 513, 514 (2d Cir. 1935). It is important to keep in mind that "there is no magic in words" and that the use of such terms as "licenses" rather than "sales" does not solve anything. Irving Berlin v. Commissioner, 42 B.T.A. 668, 674 (1940) ; See also Jefferson Gas Coal Co. v. Commissioner of Internal Revenue, 52 F.2d 120, 122 (3rd Cir. 1931). 
perpetual assignment of the exclusive motion picture rights in his copy* righted play were taxable as capital gains or as ordinary income. In Goldsmith v. Commissioner, ${ }^{64}$ the Court affirmed the decision of the Tax Court ${ }^{65}$ denying to the author the benefit of the capital gains tax. Judge Chase, writing for a court unanimous in result but not in theory, pointed out that a copyright owner "can assign separately to whomsoever he may desire one or more of the sum of the separable rights which together make up the copyright property" but that, "when he does split off such rights by assignment the assignee does not become the owner of the copyright itself and acquires only what lesser rights are granted by the terms of the assignment." ${ }^{\circ 6}$ In other words, Judge Chase, citing the copyright cases discussed above, accepted the theory of the indivisibility of the copyright ${ }^{67}$ as sufficient to exclude the transaction from the capital gains tax..$^{68}$

The second opinion in the same case was written by Judge Learned Hand, with whom Judge Swan concurred. He rejected the dogma of indivisibility:

"An exclusive license requires the author to protect the licensee against other infringement, and is for most purposes treated as 'property.' I think that it is 'property' within section 117(a)(1); that its grant is a 'sale'; . . . It does not unduly strain the meaning of 'sale' to make it include an exclusive license." "99

However, Judge Hand held that the payments received by Mr. Golclsmith could not be taxed as capital gains since the defendant was a professional writer and therefore the property involved was "held by the taxpayer primarily for sale to customers in the ordinary course of

64. 143 F.2d 466 (2d Cir. 1944), cert. denied, 323 U.S. 774 (1944), noted 20 N.Y.U.L.Q.Rev. 367 (1945).

65. 1 T.C. 711 (1943).

66. Goldsmith v. Commissioner, 143 F.2d 466, 467 (1944).

67. His characterization of the various rights included in the copyright as "separable" is strangely inconsistent with this conclusion. Id. at 467.

68. "In this instance there was no sale of the copyright since title remained in the assignor and therefore no asset, capital or otherwise, was sold." Ibid. It may be noted that Mr. Goldsmith had agreed to permit Paramount Pictures, Inc., to sue in his name, but for its own benefit and at its own expense, to enjoin infringement and to recover damages. In any such infringement suit Goldsmith would have been at most only a nominal party plaintiff. Judge Chase's opinion did not discuss an additional ground relied upon by the Tax Court that, even if there had been a sale, it cotld not have been the sale of a capital asset since it involved property used in the trade or business of the taxpayer which is subject to the allowance for depreciation under $\$ 23(1)$ of the Internal Revenue Code and, hence, excluded from the definition of "capital asset" by $\$ 117$ (a) (1) of the Code. See note 62 supra.

69. Id. at 467,468 . 
his trade or business" and thus excluded from the capital gains tax by express statutory provision. ${ }^{70}$

Although Mr. Goldsmith derived no comfort from this jurisprudential controversy, its practical significance is plain enough. According to Judge Chase, the capital gains tax would never be applicable except in the case of a sale "in one package" of the entire bundle of rights by someone who is not a professional writer or artist-like General Eisenhower. On the other hand, if Judge Hand's view should prevail, then property "sold" by non-resident alien authors by means of exclusive and perpetual licenses would be free from taxation-because nonresident aliens are exempted from any tax on gains derived from the sale of property in the United States. ${ }^{71}$ Similarly, Americans granting such licenses would benefit from the lower tax rate on capital gains, at least so long as they are not affected by the exception clause which barred Mr. Goldsmith. This group would certainly include the widow, children or other heirs of the author who obtain the copyright by inheritance and who would seem to be most deserving of such favorable treatment ${ }^{72}$ in addition, it would include artists and writers whose "trade or business" is not art or writing, ${ }^{73}$ and who would thus no

70. INT. REv. CoDE, $\$ 117$ (a)(1). Mr. Goldsmith had stated in his income tax: return that he was in "business" as a playright.

71. Since INT. Rev. CODE $\$ 117$ (a) (1) does not apply to non-resident aliens, exception clauses contained in that section relating to property held for sale to customers also do not apply. See note 79 infra. For background and discussion of the excomption, see SEN. REP. No. 2156, 74th Cong., 2nd Sess., 21 (1936); 15im. 4471, XV-2 Cum. Bull. 112 (1936) ; INT. REv. CodE $\$ 211$; Wodehouse v. Commissioner of Internal Revenue, 166 F2d 986, $98 S$ (4th Cir. 194S). A committee of the House of Representatives has recently recommended a change in the law which would require non-resident aliens to pay taxes on capital gains realized in the United States. Report of the Select Committee to Investigate Commodity Transactions. H.R. REP. No. 2025, 80th Cong., 2d Sess. 17 (1948).

72. 61 Srat. 652 (1947), 17 U.S.C. \$2S (Supp. 1948) provides that the copyright may be bequeathed by will; 61 STAr. 652 (1947), 17 U.S.C. $\$ 24$ (Supp. 1948); permits a renewal copyright in favor of the author's next of kin. Sce Reynolds v. Comm's of Internal Revenue, 155 F.2d 620 (1st Cir. 1946). In most countries of Europe and South America, the copyright continues for a specific period varying from twenty to cighty years after the author's death. 1 Ladas, International Protection: of Limsisu aid ArmisTIC. Property 316 (1938). The first French law of this lind was passed in 1793 after the deputies had been advised that "the descendants of the great Corneille have tren es:tinguished by poverty." 1 Lyou-Caen, LoIs Frarchases et Etrarigènes Sur LA Proprí́té Littíraire et ARistique is (1889).

73. "The facts necessary to create the status of one engaged in a 'trade or business" revolve largely around the frequency or continuity of the transactions claimed to result in a 'business' status." Commissioner v. Boeing, 106 F.2d 305, 309 (9th Cir. 1939), cert. denied, 308 U. S. 619 (1939) ; "a person may be engaged in more than one business. ... Carrying on a business, however, implies an occupational undertaling to which one habitually derotes time, attention or effort with substantial regularity." Fahs v. Crawford, 161 F.2d 315, 317 (5th Cir. 1947). See Note, 106 A.L.R. 254 (1937). When property deemed to be stock in trade of taxpayer or property held by him primarily for sale 
longer be compelled to resort to "one package" transactions in order to avoid the higher tax rate on ordinary income.

When the Rohmer case ${ }^{74}$ arose, the Second Circuit had an opportunity to settle the fundamental difference between the two conflicting philosophies of the Goldsmith case. Instead, it increased rather than eliminated the existing obfuscation. In the Rohmer case, a non-resident alien author had claimed immunity from taxation with respect to a lump sum payment received by him for the grant of the exclusive and perpetual right to magazine and newspaper publication of his novel in the United States. The court unanimously affirmed the decision of the Tax Court which had held that the payment to Rohmer was taxable as a "fixed or determinable" profit, and therefore as ordinary income, pursuant to section 211 (a)(1)(A) of the Internal Revenue Code; ${ }^{75}$ it was not a purchase price for the sale of personal property. In reaching this result, the court did not expressly repudiate Judge Hand's opinion in the Goldsmith case but attempted to distinguish that case by arguing that the judicial controversy in the Goldsmith case had no bearing on the tax liability of a non-resident alien. ${ }^{70}$ With respect to such liability, the court based its decision on the indivisibility of the "bundle of rights" conferred by the copyright; transfer of less than the entire "bundle" was said to be only "the grant of a license" and the payments for such a grant were held to constitute ordinary income in the form of royalties, whether made in installments or in one single amount. ${ }^{77}$

in the course of his trade or business within the provisions of the Federal income tax statutes excluding such class of property from the category of capital assets. See also 20 N.Y.U.L.Q.REv. 367, 370-373 (1945). Accord; Myers v. Commissioner, 6 T. C. 258, 266 (1946), where gain of taxpayer, a salaried employee who had transferred to the Goodrich Company "his one and only invention," was taxed as capital gain. Cf. Avery v. Commissioner, 47 B. T. A. 538, 541 (1942). The 1942 amendment of section 23 (1) of the Internal Revenue Code, which extended the depreciation allowance to property held for the production of income, would seem to be irrelevant since section 117 (a) (1) excludes from the definition of "capital asset" only property "used in the trade or business" subject to depreciation.

74. 153 F. 2d 61, 63 (2d Cir. 1946), affirning, 5 T.C. 183 (1945). Discussion of the Tax Court decision is found in Miller, Taxation of Income from Litcrary Property Onented By Non-Resident Aliens, 54 YaLE L.J. 879 (1945). The circuit court opinion was written by Judge Frank, with whom Chase and Swan, JJ, concurred.

75. This is the provision which imposes a tax on non-resident aliens with respect to income derived from sources within the United States. Accord: Molnar v. Commissioner, 156 F.2d 924 (2d Cir. 1946) ; note, 47 Cor. L. Rev. 160 (1947); Estate of Marton v. Commissioner, 47 B.T.A. 184 (1942); see also Ehrlich v. Higgins, 52 F. Supp. 805 (S.D.N.Y. 1943).

76. Rohmer v. Commissioner, 153 F.2d 61, 65 (1946).

77. Id. at 63 . On p. 64 the court said with respect to its interpretation of $\$ 211$ (a) (1) of the Internal Revenue Code: "We confess that the congressional purpose is not crystalclear and that the legislative history does not put beyond all conceivable doubt the purpose to impose a tax on such transactions. ..." 
The reasons advanced by the court for avoiding a clear-cut choice between the two rationales of the Goldsmith case are untenable. The mere fact that the Rohmer case deals with non-resident aliens while the Goldsmith case does not, hardly proves a dissimilarity of the underlying legal issues. In both situations, the criteria for identifying the transaction as a sale of a capital asset should be the same. Once a finding of sale is made, however, the tax consequences vary: the nonresident alien is completely exempted from any tax on gains from the sale of his property, ${ }^{78}$ even under ordinary income tax provisions; ${ }^{70}$ and where residents and citizens are concerned, judicial declaration that a sale has taken place results in subjection to taxation rather than immunity from it. Thus, whether non-resident aliens or resident citizens are involved, the term "sale" is given content by reference to the same body of substantive law-here, the copyright law and its theory of the indivisibility of the copyright.

The failure of the court to recognize the basic similarity of the two cases would seem to indicate that the invocation of technical niceties in the Rohmer case to distinguish it from the Goldsmilh case was unsuccessful; in substance, the Rohmer decision, by denying tax exemption to the non-resident alien, amounts to a finding of no sale and therefore, to ratification of Judge Chase's opinion in the Goldsmith case. Judge Learned Hand's approach has apparently been disapproved.

Frank adoption of the indivisibility doctrine in the Rolmer case would have been less confusing. It would also have removed some of the difficulties encountered by the court in interpreting the meaning of "fixed or determinable annual or periodical gains, profits, and income" in sections 211 and 143(b). The fact that payments are made in a lump sum or in several installments is not alone determinative of whether or not there has been a sale for tax purposes; and as much is indicated by the finding of no sale in the Rolmer case where a lump sum payment was made. Instead, the nature and purpose of the payments is the controlling factor. ${ }^{00}$ For instance, an inventor may enter into an agreement for the sale of his patent pursuant to which the purchaser undertakes to make both a fixed payment and other periodic payments based on a percentage of profits or on production; there may

78. See note 71 supra. See also INT. REv. CODE $\$ 143$ (b) relating to withholding of income tax at source on income earned by non-resident aliens.

79. Regulations of the Bureau of Internal Revenue specifically state that "the income derived from the sale in the United States of property, whether real or personal, is not fixed or determinable annual or periodical income" within reach of the provisions governing the withholding of taxes owed by non-resident aliens. Regulation 111, $\$ 29.143-2 ; 2$ P.H. FED. TAX SERV. $\$ 18,251$ (1946); INr. Kev. CODE $\$ \$ 143$ (b), 211 (a) (1)(A). 10 MFertens, LaW of Federal In ConIE Taxation \$ 56.21 (1942).

80. Rohmer v. Commissioner, 5 T.C. 183, 187 (1945). 
even be no fixed payment at all. While this mode of payment may resemble royalties, the courts will nevertheless hold that it is actually an installment plan for paying the purchase price, if the intention was to transfer full title to the property..$^{81}$ On the other hand, a lump sum payment might be the equivalent of an advance computation of future rents or royalties. ${ }^{82}$ In any event, the method of payment is not the sole criterion of "sale." But once a court decrees that a sale has been made, the payments received by the seller are outside section 211 (a)(1)(A), whether or not they are made in installments. Thus, labelling a given transaction a sale forecasts the tax result: non-resident aliens receive tax immunity, and for all other taxpayers the cap. ital gains provisions come into play-provided the six month holding provision has been satisfied.

The last stage, at this writing, was reached in Wodehouse v. Commissioner ${ }^{83}$ Wodehouse had sold several of his stories to the publisher of the Saturday Evening Post with the understanding that the Post would obtain the copyright, but would, after publication, reassign to the author all rights except the American and Canadian rights of magazine publication. The Tax Court, following the Rohmer case, held that the lump sum payment received by Wodehouse in consideration of this agreement was taxable income under section 211 (a)(1)(A), but the Circuit Court of Appeals for the Fourth Circuit, Judge Dobie dissenting, reversed in a sweeping disapproval of the Rohmer decision. That court analyzed the theory of indivisibility of the copyright and found that it was, at most, only concerned with procedural matters. Since Congress declared that non-resident aliens should not be subject to the capital gains tax, the court concluded "That the will of Congress is frustrated when that which is generally recognized in the commercial exploitation of literary works as a sale is subjected to the incidence of the tax under a different name." 84 The majority of the court squarely rejected the indivisibility theory as a criterion for determination of the tax issue. In view of this conflict of decisions, the problem must now be decided by the Supreme Court.

81. Commissioner v. Hopkinson, 126 F.2d 406, 410 (2d Cir. 1942), affirming, 42 B.T.A. 580 (1940) ; Kimble Glass Co. v. Commissioner, 9 T.C. 183, 190 (1947). Sce Lourie and Cutler, Capital Assets Sold On The Installment Basis, 26 Taxes 707 (1948).

82. Rohmer v. Commissioner, 153 F. 2d 61, 63 (1946).

83. 8 T. C. 637 (1947), revid, 166 F.2d 986 (4th Cir. 1948) ; Notes, 34 U. VA. L. REV. 617 (1948), 48 CoL. L. REv. 967 (1948); cert. granted, 17 L.W. 3090 (Oct. 11, 1948).

84. 166 F.2d 986, 990 (4th Cir. 1948). (Italics supplied.) The court added that it would be inconsistent to exempt entirely a sale of the copyright as a whole but to tax "the proceeds of separate sales of parts of the whole." The court also rejected the construction placed upon the phrase "fixed or determinable annual or periodical gains" by the Second Circuit, 166 F.2d at 991, 992. 
The blurred lines of the chaotic picture at which we have been gazing throughout these pages must be redrawn. Its substitute must be based on business realities and must recognize that, by the grant of an exclusive and perpetual "license," the grantor irrevocably and finally transfers to the "licensee" a substantial and valuable asset. The contention that such a transfer does not involve a property right and therefore no "sale" has taken place is at odds with contemporary tax law which purports to ignore formalistic standards of interpretation. ${ }^{35}$ Even Judge Frank, who wrote the opinion in the Rolmer case, recognized that the essence of property is the right of its owner, "enforceable by court action, to exclude others from its use, absent his consent"; he added that "power to exclude is what 'monopoly' ordinarily means." \&5 Surely, that description fits the exclusive and perpetual licensee of any one of the rights included in the "bundle." Indeed, the only difference between such a licensee and the owner of the "bundle" would seem to be that the quantity of the rights granted to the former is smaller; ${ }^{57}$ qualitatively, both enjoy the same attributes of property.

85. Parke, Davis \& Co. v. Comm'r, 31 B.T.A. 427, 431 (1934). See also MicAllister v. Comm'r, 157 F.2d 235 (2d Cir. 1946), cert. denied, 330 U.S. $\$ 26$ (1947).

S6. Rohmer v. Commissioner, note 74 sipra, at 63, n. 9; Seattle Brewing \& Mralting Co. v. Commissioner, 6 T. C. S56, 86S (1946), aff'd, 165 F.2d 216 (9th Cir. 1948), rehearing denied, 166 F.2d 326 (9th Cir. 1948).

87. "But we are clear that distinctions attempted on the basis of the various legal names given a transaction, rather than on its actual results between the parties, do not afford a sound basis for its delimitation." McAllister v. Commissioner, sispro, note 85: Release by life tenant of her interest in testamentary trust and consent to its termination in consideration of payment of lump sum by remainderman held sale of capital asset on the ground that her "right to income for life from the trust estate was a right in the estate itself. Had she held a fee interest, the assignment would unquestionably have been regarded as the transfer of a capital asset; we see no reason why a different ressll shousld follow the transfer of the lesser, but still substantial life intcrest." (Italies supplied.) Id. at 236. Accord; Allen v. First National Bank and Trust Co. of Alacon, 157 F2d 592 (5th Cir. 1946), cert. denied, 330 U. S. 828 (1947). See Blair v. Commissioner, 300 U. S. 5 (1937). Comments, 56 Yale L. J. 570 (1947), 14 U. of Cri. L. Rev. 484. (1947) ; 16 Ford. L. REv. 123 (1947).

It was held in Sabatini v. Commissioner, 98 F.2d 753, 755 (2d Cir. 1938) that a grant of exclusive world-wide motion picture rights by a British author for a sfated period was not a sale. Subsequently, the same court, in the Rohmer case discussed in the test, observed that even in the absence of a time limitation no sale could be recoznized. In contrast, patent cases have repeatedly held that contractual provisions permitting a seller of patent rights to terminate the agreement under certain specified circumstances merely

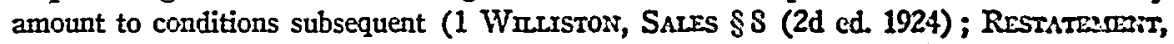
Property, $\$ 24$ (1936)) and therefore do not preclude a tax classification of the amounts received by the seller as gains from the sale of capital assets. Sec Commissioner v. Celanese Corp., 140 F.2d 339 (D.C.Cir. 1944) ; Mryers v. Commissioner, 6 T.C. 258, 264 (1946) ; Kimble Glass Co. v. Commissioner, 9 T.C. 183 (1947). But compare Federal Laboratories v. Commissioner, S T.C. 1150 (1947), where licensor recerved full title. See also Greenlee and Kramer, Capital Gains on Sale of Patents, 26 TAxEs 779 (1948). Although 
Excellent guideposts for the ultimate solution of the problem are provided by one patent and two trade-mark cases. In Parke, Davis \&s Co. v. Commissioner, 88 the taxpayer entered into a "license" agreement with a competitor purporting to "sell and grant" to the latter "the exclusive right, license and privilege to manufacture and have manufactured for its exclusive use, and to use but not to sell," the inventions covered by the taxpayer's patents. The latter was to receive four specific payments from the "licensee" in consideration of such transfer. Both parties agreed not to grant any license nor to sell the articles manufactured without the consent of the other. Infringement suits were to be brought by the "licensor," but both parties were to share equally the expenses and proceeds of any such litigation. The Commissioner contended that the payments received by the "licensor" were taxable as income on the ground that only the right to make and use, but not the right to sell was transferred, and that the licensor alone could sue for infringement. The Board of Tax Appeals, however, sustained the contention of the "licensor" that the transaction was a transfer of a one-half interest in the patents and the payments represented merely a return of the amount invested in such patents. Referring to the patent cases which had held that a "licensee" who acquired less than all the rights in the patent did not obtain legal title and, hence, could not sue for infringement, ${ }^{89}$ the Board pointed out that the right to maintain a suit at law is controlled by the question of the possession of "the naked legal title." That question was deemed to be "entirely different" from the tax problem presented. In the tax case, "legal title" is of little consequence and the inquiry is as to the ownership of the beneficial interest. ${ }^{90}$ And the solution of that was determined solely by the fact that the licensor had "divested itself irrevocably of certain capital investments in consideration of the payment made to it." ${ }^{11}$ Similarly, in Rainier Brewing Co. v. Commissioner ${ }^{02}$ and in Seattle Brewing \& Malting Co. v. Commissioner ${ }^{93}$ the Rainier Co. had granted to the Seattle Co. an exclusive license to use Rainier's trade-mark in connection with the sale of alcoholic malt beverages in the State of Washington and the Territory of Alaska. Rainier retained

there might well be a difference between a transfer for a stated period and a possibility of divestment of the buyer's title in some particular contingency, the Government's contention that, for tax purposes, a sale should be recognized only where there is no possibility of the property being recaptured by the seller, appears sound.

88. 31 B.T.A. 427 (1934).

89. Gayler v. Wilder, Waterman v. Mackenzie, note 24 supra.

90. 31 B.T.A. 427, 431. Compare Cleveland Graphite Bronze Co. v. Commissioner,

10 T. C. 974,988 (1948).

91. Ibid.

92. 7 T. C. 162 (1946), aff'd per curiam, 165 F.2d 217 (9th Cir. 1948).

93. 6 T. C. 856 (1946), aff'd per curiam, 165 F.2d 216 (9th Cir. 1948). Sce also United States v. Adamson, 161 F.2d 942 (9th Cir. 1947). 
the right to manufacture and sell its beer under that trade-mark outside the area specified and to use its mark anywhere in connection with non-alcoholic beverages. After the agreement had been in force for five years, the Seattle Co. exercised its option to terminate all payments of royalties to Rainier against a payment of a lump sum. The Tax Court held that the sum received by Rainier for the exclusive and perpetual right to use its trade name in the manufacture and sale of alcoholic malt beverages within the limited territory was not ordinary income but a capital transaction and taxable as such. ${ }^{94}$ By the same token, the Seattle Co. was not permitted to deduct the payment made to Rainier on the ground that it was the purchase price for a capital investment. ${ }^{95}$ Citing Judge Hand's opinion in the Goldsmilh case and the Board's opinion in the Parke, Davis Co. case, the court pointed out that the owner of a trade-mark or trade-name, like the owner of a copyright or patent, has a monopoly which is a property right and which he may assign or transfer even in a limited territory. "If such grant is exclusive and perpetual, its characteristics more resemble a sale than a license"; ${ }^{97}$ the retention of the naked legal title by the grantor was held to be immaterial.9s

94. 7 T. C. 162, 174 (1946). The only possible caveat with respect to the Scallie Breacing Co. case, note 86 supra, might involve a question as to the correct interpretation of the facts by the Tax Court. The Court noted that under the agreement Seattle could not assign the rights granted to it by Rainier without the latter's consent, but that this was not controlling since Rainier could not assign the same rights to another or use them itself. $6 \mathrm{~T}$. C., at $\$ 69$. The question may well be raised how such a restriction on the right of alienation can be reconciled with the characterization of the transfer as a sale.

95. Seattle Brewing Co. v. Commissioner, note 93 supra. It is generally held that the cost of eliminating competition is a capital investment, Newspaper Printing $C_{0} . v$. Commissioner, 56 F. 2d 125, 127 (3rd Cir. 1932), affrming 17 B.T.A. 452 (1929), and not an ordinary and necessary business expense, since the expenditure is usually made for many years to come and the benefits derived therefrom cannot be confined to any single year; therefore the cost cannot be charged against income earned in that year. Clarl: Thread Co. v. Commissioner, 100 F.2d 257, 258 (3rd Cir. 1938), affirning 2S B.T.A. 1123 (1933) ; J. I. Case Co. v. United States, 32 F. Supp. 754, 761, 762 (Ct. Cl. 1940). Cf. International Textbook Co. v. United States, 44 F. 2d 254, 257 (Ct. Cl. 1930).

96. Seattle Brewing Co. v. Commissioner, 6 T. C. $\$ 56,868,869,873$ (1946). A splitting up of the right on a geographical basis appears less feasible with respect to the copyright than with respect to patents or trademarks. However, even in the copyright field an arrangement of this kind would be possible, for instance a grant of the right of dramatic production limited to certain cities.

97. Id. at $\$ 69$.

98. Ibid. See also, General Aniline and Film Corp. v. Commissioner, 139 F.2d 759, $760 \mathrm{n.} 2$ (2d Cir. 1944), where the court said: "It seems to us to be of no signifiance with respect to the transfer of title, whether, when a patent is assigned (a) the arsignce simultaneously grants a license to the assignor, or (b) the assignor reserves a lieense; such differences in form would seem to be immaterial. Nor does it seem to us important, ... 
Acceptance of the view that the grant of an exclusive and perpetual license is a sale for tax purposes would assure tax exemption to nonresident aliens and the lower tax rate on capital gains to all other taxpayers except those barred by the "trade or business" clause of section 117(a)(1). This result is the only one which would translate into positive law the policy of the capital gains tax. That policy, designed to provide tax relief for profits realized from the sale of long-term investments, would seem to draw within its scope the grantor of an exclusive and perpetual "license" of any one of his several rights as well as the seller of a share of stock or of a piece of land; both convey their asset finally and irrevocably to another, for a consideration. The gain derived from such a conveyance has accrued over a period of time and therefore should not be taxed at the full rate when the asset is given up. This consideration is particularly appropriate in the case of authors and inventors who frequently reap the reward for their labors only after a long period of work. Even in non-capital gains cases, Section 107(b) of the Internal Revenue Code recognizes the need for tax relief for professional authors and inventors who have worked on an artistic work or invention for a period of at least three years and who receive $80 \%$ or more of all royalties from such work in any one year; they are permitted to reduce their ordinary income tax liability by averaging such income over the whole period. ${ }^{90}$ The application of the lower tax rate on long term capital gains in those situations where an exclusive and irrevocable sale has taken place thus represents merely a necessary and logical corollary to the policy laid down, however inadequately, in Section 107(b). ${ }^{100}$

The approach outlined above leads, then, to final approval of the opinion of the Fourth Circuit in the Wodehouse case, of Judge Hand's concurring opinion in the Goldsmith case, and of the patent and trademark cases discussed above. The lower tax rate for capital gains would thus be available to residents of the United States (except, of course, professional authors who are ineligible under $\$ 117$ (a) (1)) without the requirement of "one package" sales.

However, the question arises as to whether that solution would go far enough. A bill recently introduced in Congress would go even further by providing that all moneys received by an author or composer upon assignment of motion picture rights in a literary, dramatic, or musical work created by him shall be considered as amounts re-

that the assignor, before making the assignment, had granted to others some rights under the patent." But cf. Rohmer v. Commissioner, note 74 supra at 64, n. 16.

99. Vernon, Some Current Problems under Section 107, 1 TAx L. Rev. 357, 358, 365 (1946).

100. See the excellent discussion in Swartz, Authors and the Federal Income Tax, 26 TAXES 51, 56 (1948). 
ceived from the sale of a capital asset if held for more than six months. ${ }^{101}$ The obvious vice of this proposal is its limitation to only one of the many rights included in the "bundle." If the theory of indivisibility is to be demolished by legislation, such legislation should be applicable to each one of the several rights. On the other hand, the bill's purpose of applying the capital gains tax to professional writers and artists by removing the "trade or business" restriction of section $117(a)(1)$ deserves serious consideration. ${ }^{102}$ The proposal is, of course, not consistent with the traditional scheme of the tax on long term capital gains which was not designed to cover earnings from the taxpayer's trade or business. However, as already indicated, the acquisition of copyrights as well as patents usually requires a considerable investment over a considerable period of time; any gain from a sale of any of the rights included in the "bundle" thus accrues during a period which in many cases exceeds the span of one taxable year. The argument for application of the capital gains tax in this particular field is, therefore, at least as strong as in the field of casual, irregular or fortuitous gains-the traditional area of that tax. Yet this last mentioned phase of the problem could just as easily be handled by a liberalization of the already-mentioned narrow provisions of present Section 107(b) of the Internal Revenue Code, which permit, under limited conditions, income received in any one year from copyrights and patents to be averaged over a period of years.

Regardless of the particular solution which is finally accepted, society's interest in treating creators of cultural and scientific values fairly requires that the theory of indivisibility be abandoned. Substitution of the view that an exclusive and perpetual license of any one of the "bundle of rights" of the copyright or patent grant is a sale for capital gains tax purposes would result in more equitable treatment of the irregular and variable incomes of authors and inventors.

101. H. R. 5562, S0th Cong., 2d Sess. 194S: A Bill to amend section 22 of the Internal Revenue Code (introduced February 25, 1948 by Mir. Hugh D. Scott, Jr. "by request"). 102. The bill is drafted as a proposed amendment to section 22 of the Internal Revenue Code which defines "gross income" In effect it males inzpplicable to authors and composers the exception clause of section 117 (a) (1) which excludes "property held by the taxpayer primarily for sale to customers in the ordinary course of his trade or business" from the definition of the term "capital asset." 